\title{
Pola kerjasama kepala desa dengan badan permusyawaratan desa dalam pembangunan desa
}

\section{A Zarkasi, \& Dimasrizal*}

Universitas Jambi

\section{*dimasrizal@unja.ac.id}

\begin{abstract}
Abstrak. Pemerintahan desa merupakan unit terdepan dalam pelayanan kepada masyarakat serta menjadi tonggak strategis untuk keberhasilan semua program yang dijalankan Pemerintah Pusat dan Pemerintah Daerah. Pembangunan desa akan dirancang pada musyawarah pembangunan desa antara Pemerintah desa dan Badan Permusyawaratan Desa serta tokoh masyarakat. Kendala yang dihadapi oleh mitra adalah persoalan tentang bagaimana pola kerjasama yang seharusnya terjalin antara Kepala Desa dan Badan Permusyawaratan Desa dalam proses pembangunan desa. Pemerintahan Desa dalam hal ini Desa Petajen Kecamatan Bajubang Kabupaten Batanghari dalam menampung dan menyalurkan aspirasi masyarakat untuk merancang pembangunan desa. Berdasarkan permasalahan mitra tersebut maka metode yang digunakan dalam pengabdian ini yaitu dengan melakukan penyuluhan, serta melakukan monitoring evaluasi terhadap mitra pengabdian yaitu Desa Petajen. Dari hasil evaluasi yang dilakukan ditemukan pesoalan mitra yaitu kurangnya pengetahuan antara Kepala Desa dengan Badan permusyawaratan Desa dalam hal pembangunan desa. Temuan lain juga menunjukkan bahwa kurangnya pengetahuan aparatur desa dikarenakan tingkat pendidikan yang rendah serta tidak adanya bimbingan teknis yang diberikan oleh pemerintah daerah kepada anggota Badan Permusyawaratan Desa dalam meningkatkan pembangunan desa. Oleh sebab itu, perlu dilakukan pendampingan lebih lanjut dalam peningkatan kemampuan kerjasama antara Kepala Desa dengan Badan Permusyawaratan Desa untuk meningkatkan pembangunan desa.
\end{abstract}

Kata kunci: pemerintahan desa; pembangunan desa; tokoh masyarakat

To cite this article: Zarkasi, A., \& Dimasrizal. 2019. Pola kerjasama kepala desa dengan badan permusyawaratan desa dalam pembangunan desa. Unri Conference Series: Community Engagement 1: 652-657 https://doi.org/10.31258/unricsce.1.652-657

\section{(C) 2019 Authors}

Peer-review under responsibility of the organizing committee of Seminar Nasional Pemberdayaan Masyarakat 2019 


\section{PENDAHULUAN}

Menurut Undang-Undang No. 23 tahun 2014 otonomi daerah adalah hak, kewenangan, dan kewajiban daerah untuk mengatur dan mengurus rumah tangganya sendiri sesuai dengan peraturan perundang-undangan yang berlaku. Setiap daerah di Indonesia diberikan hak untuk melakukan otonomi daerah dengan memberikan kewenangan yang luas, nyata dan bertanggung jawab yang dapat menjamin perkembangan dan pembangunan daerah. Dalam pelaksanaan otonomi daerah diharapkan setiap daerah mampu berkreasi dalam mencari sumber penerimaan yang dapat membiayai pengeluaran pemerintah daerah dalam rangka menyelenggarakan pemerintahan dan pembangunan pada berbagai sektor. Karena dalam prinsipnya, daerah dituntut untuk mandiri dalam menciptakan berbagai potensi daerah yang dapat diandalkan.

Berbeda antara otonomi daerah dengan otonomi desa karena pada otonomi desa kewenangan datangnya dari bawah yang diberikan oleh masyarakat desa itu sendiri maka pada otonomi daerah kewenangan datangnya dari pemerintah pusat. Pelaksanaan otonomi daerah akan sangat bergantung pada kesiapan pemerintah daerah dalam menyusun sistem pemerintahannya agar tercipta pembangunan yang efisien, efektif, akuntabilitas dan transparansi serta mendapatkan pasrtisipasi dari masyarakat dalam penyelenggaraan pemerintahannya (Abdullah, R: 2011).

Penyelenggaraan Pemerintahan Desa tidak terpisahkan dari penyelenggaraan otonomi daerah, dimana penyelenggaraan Pemerintahan Desa merupakan unit terdepan (ujung tombak) dalam pelayanan kepada masyarakat serta menjadi tonggak strategis untuk keberhasilan semua program yang dijalankan Pemerintah. Meskipun titik berat otonomi daerah terletak pada tingkat kabupaten/kota, namun pada praktek sebenarnya desa mempunyai peranan yang sangat penting. Selama ini pembangunan desa masih banyak bergantung dari Pendapatan Asli Daerah dan Swadaya Masyarakat dimana jumlah maupun sifatnya tidak dapat diprediksi.

Pembangunan pada prinsipnya merupakan usaha pertumbuhan dan perubahan yang berencana yang dilakukan secara sadar oleh suatu bangsa, negara dan pemerintah untuk menuju modernisasi dalam rangka mensejahterakan rakyat baik secara lahir maupun batin. Dalam pembangunan terjadi suatu proses perubahan yang berlangsung secara terus menerus dan berkelanjutan. Disinilah peran pemerintah harus lebih jeli menggerakkan masyarakat agar berpartisipasi dalam pembangunan serta mampu mengembangkan potensi yang dimiliki negara, untuk mencapai tujuan dan cita-cita bangsa, karena pada dasarnya pembangunan diselenggarakan oleh rakyat bersama pemerintah. Peranan masyarakat dalam pembangunan harus ditumbuhkan, dengan mendorong kesadaran, pemahaman dan penghayatan, bahwa hak, kewajiban dan tanggung jawab seluruh masyarakat, maka hasil hasil dari pembangunan dapat dinikmati oleh seluruh rakyat (Ketaren, S : 2008).

Pembangunan yang dilaksanakan di pedesaan atau tingkat Keluruhan merupakan realisasi pembangunan nasional. Untuk menunjang pembangunan di pedesaan atau tingkat Desa peran serta Badan Pemusyawaratan Desa, pemerintah serta partisipasi seluruh lapisan masyarakat sangat dibutuhkan. Dalam Penyelenggaraan Pembangunan, perencanaan merupakan salah satu faktor yang sangat menentukan keberhasilan sehingga dalam Undang-undang Nomor 23 Tahun 2014 ini, perencanaan pembangunan daerah diatur dalam satu bab tersendiri. Hal ini membuktikan bahwa pembuat undang-undang menyadari sepenuhnya bahwa masalah perencanaan dalam pelaksanaan pembangunan daerah harus mendapat perhatian.

Pengertian tentang pemerintahan desa diatur di dalam Ketentuan umum Pasal 1 ayat (2) Undang-undang Nomor 6 Tahun 2014 tentang Desa yang bunyinya "Pemerintahan Desa adalah penyelenggaraan urusan pemerintahan dan kepentingan masyarakat setempat dalam sistem pemerintahan Negara Kesatuan Republik Indonesia". Pemerintah desa merupakan penyelenggaraan pemerintahan yang kedudukan paling terendah yang mempunyai kewenangan didalam mengatur kepentingan masyarakat setempat yang ada diwilayahnya. Didalam menjalankan pemerintahnya, pemerintahan desa terdiri atas Pemerintah Desa, Perangkat Desa dan Badan Pemusyawaratan Desa (BPD) yang mempunyai fungsi dan kewenangan yang berbeda. Pemerintah desa yang juga disebut Kepala Desa merupakan pimpinan penyelenggaraan pemerintahan desa berdasarkan kebijakan yang ditetapkan bersama Badan Permusyawaratan Desa (BPD).

Dalam UU NO 6 Tahun 2014 tentang desa dijelaskan pembangunan desa adalah upaya peningkatan kualitas hidup dan kehidupan untuk sebesar-besarnya kesejahteraan masyarakat desa. Dalam proses pembangunan desa harus adanya kerja sama yang baik dari seluruh perangkat pemerintahan desa guna untuk kepentingan masyarakat banyak. Rendahnya pembangunan desa bisa diakibatkan oleh kurangnya kerjasama antara perangkat pemerintahan desa.

Oleh karena itu, pembangunan desa akan dilaksanakan pada musyawarah pembangunan desa antara pemerintahan desa. Pemerintahan desa berfungsi untuk menampung dan menyalurkan aspirasi masyarakat 
dalam memenuhi kebutuhan hidup dan penghidupannya. Oleh karena itu yang menjadi fokus persoalan penulis dalam hal ini yaitu pola kerjasama pemerintahan desa dalam pembangunan desa. Apakah pemerintahan desa sudah melaksanakan perannya dalam pembangunan desa sesuai dengan peraturan yang sudah ditetapkan.

\section{Masalah}

Disamping Kepala Desa, pemerintahan desa dilengkapi dengan Badan Permusyawaratan Desa (BPD). Keberadaan BPD ini sebagai perwujudan demokrasi ditingkat desa yang bertujuan sebagai wadah menyalurkan aspirasi masyarakat desa. BPD disamping lembaga penampung aspirasi masyarakat desa diharapkan dapat mengembangkan budaya tingkat desa dan mempunyai fungsi penting lainnya sebagai badan legislasi desa, dan pengawasan dalam pelaksanaan Peraturan Desa, dan penyerapan Anggaran Pendapatan dan Belanja Desa.

Selain BPD, kepala desa dibantu oleh perangkat desa. Perangkat desa diangkat langsung oleh kepala desa setelah dikonsultasi dengan camat atas nama bupati/walikota. Perangkat desa terdiri atas sekretaris desa, pelaksana kewilayahan, pelaksana teknis. Perangkat desa bertugas membantu kepala desa dalam melaksanakan tugas dan wewenangnya, serta bertanggungjawab langsung kepada kepala desa.

Kemudian kewenangan desa mencakup kewenangan yang sudah ada berdasarkan hak asal usul desa, kewenangan yang oleh peraturan Perundang-undangan yang berlaku belum dilaksanakan oleh daerah dan pemerintah serta tugas pembantuan baik yang diberikan oleh pemerintah pusat maupun Pemerintah Provinsi dan atau Pemerintah Kabupaten/Kota. Dalam rangka melaksanakan penyelenggaraan pemerintahan desa diperlukan pembiayaan baik yang bersumber dari keuangan desa itu sendiri atau pendapatan asli desa (PAD) ataupun yang bersumber dari pemerintah, baik pemerintah pusat maupun pemerintah daerah, baik provinsi maupun kabupaten.

Dari survey awal, diskusi yang dilakukan oleh tim pengabdian dengan mitra menemukan kendala yang dihadapi oleh mitra yaitu persoalan tentang bagaimana pola kerjasama yang seharusnya terjalin antara Kepala Desa dan Badan Permusyawaratan Desa dalam proses pembangunan desa. Hal ini diharapkan untuk mempercepat proses pembangunan demi kesejahteraan masyarakat di Desa Petajen Kecamatan Bajubang Kabupaten Batang Hari.

\section{METODE}

Tahapan pelaksanaan pengabdian Kepada Masyarakat yang digunakan oleh tim pengabdian dalam mensosialisasikan Tentang Pola Kerjasama Kepala Desa Dengan Badan Permusyawaratan Desa Dalam Pembangunan di Desa Petajen Kecamatan Bajubang Kabupaten Batanghari, dilakukan dengan menggunakan pendekatan participatory learning and action (PLA). Istilah lain PLA pada kegiatan pemberdayaan masyarakat yang juga dikenal dengan konsep learning by doing atau belajar sambil bekerja (Ibnouf, Sheqwarah, \& Sultan, 2015). Melalui metode PLA, pengabdian dilakukan melalui proses belajar melalui ceramah atau tutorial, curah pendapat dan diskusi, kegiatan lain.

a. Tahapan Pertama

Tim melakukan survei lokasi pengabdian kepada masyarakat untuk mengidentifikasi permasalahan yang dihadapi oleh mitra dengan melakukan diskusi dengan kepala desa dan ketua BPD Desa Petajen Kecamatan Bajubang Kabupaten Batanghari.

b. Tahapan Kedua

Tim Pengabdian Kepada Masyarakat melakukan penyuluhan kepada perangkat desa Petajen Kecamatan Bajubang Kabupaten Batanghari dengan tema Pola Kerjasama Kepala Desa Dengan Badan Permusyawaratan Desa Dalam Pembangunan Desa. Hal ini diharapkan dapat meningkatkan pengetahuan antar perangkat desa guna untuk perkembangan dan kesejahteraan masyarakat. Tahapan kedua ini meliputi Pemaparan Solusi melalui Materi yang relevan dengan permasalahan mitra, Memaparkan Materi dan contoh dengan menayangkan slide/powerpoint, serta Tanya jawab/diskusi.

c. Tahapan Ketiga

Tim Pengabdian Kepada Masyarakat melakukan monitoring evaluasi terhadap mitra. Pada tahapan ini diharapkan permasalahan yang ditemui dilapangan antar mitra dapat teratasi. Dalam hal ini tim pengabdian akan melakukan pendampingan kepada mitra. 


\section{PEMBAHASAN}

Pembangunan desa adalah upaya peningkatan kualitas hidup dan kehidupan untuk sebesar-besarnya kesejahteraan masyarakat desa. Pembangunan desa bertujuan meningkatkan kesejahteraan masyarakat desa dan kualitas hidup manusia serta penanggulangan kemiskinan melalui pemenuhan kebutuhan dasar, pembangnan sarana dan prasarana desa, pengembangan potensi ekonomi lokal, serta pemanfaatan sumber daya alam dan lingkungan secara berkelanjutan. Beberapa tahapan yang dilakukan untuk meningkatkan pembangunan desa dapat diuraikan sebagai berikut.

\section{Tahap Perencanaan}

a. Pemerintah desa menyusun perencanaan pembangunan desa sesuai dengan dengan mengacu pada perencanaan pembangunan kabupaten/kota.

b. Perencanaan pembangunan desa disusun secara berjangka meliputi :

1) Rencana pembangunan jangka menengah desa untuk jangka waktu 6 (enam) tahun.

2) Rencana pembangunan tahunan desa atau yang disebut dengan rencana kerja pemerintah desa, merupakan penjabaran dari rencana pembangunan jangka menengah desa untuk jangka waktu 1 (satu) tahun.

c. Rencana pembangunan jangka menengah desa dan rencana kerja pemerintah desa ditetapkan dengan peraturan desa.

d. Peraturan desa tentang rencana pembangunan jangka menengah desa dan rencana kerja pemerintah desa merupakan satu-satunya dokumen perencanaan di desa.

e. Rencana pembangunan jangka menengah desa dan rencana kerja pemerintah desa merupakan pedoman dalam penyusunan anggaran pendapatan dan belanja desa yang di atur dalam peraturan pemerintah.

f. Program pemerintah dan/atau pemerintah daerah yang berskala desa di koordinasikan dan/atau dideligasikan pelaksaanaannya kepada desa.

g. Perencanaan pembangunan desa merupakan salah satu sumber masukan dalam perencanaan pembangunan kabupaten/kota.

Perencanaan pembangunan desa diselenggarakan dengan:

a. Diselenggaran dengan mengikutsertakan masyarakat;

b. Menyelenggarakan musyawarah perencanaan pembangunan desa;

c. Musyawarah perencanaan pembangunan desa menetapkan prioritas, program, kegiatan, dan kebutuhan pembangunan desa yang didanai oleh anggaran pendapatan dan belanja desa, swadaya masyarakat desa, dan/atau anggaran pendapatan dan belanja daerah kabupaten/kota.

d. Prioritas, program, kegiatan, dan kebutuhan pembangunan desa dirumuskan berdasarkan penilaian terhadap kebutuhan masyarakat desa yang meliputi:

- Peningkatan kualitas dan akses terhadap pelayanan dasar;

- Pembangunan dan pemeliharaan infrastruktur dan lingkungan berdasarkan kemampuan teknis dan sumber daya lokal yang tersedia;

- Pengembangan ekonomi pertanian berskalaproduktif;

- Pengembangan dan pemanfaatan teknologi tepat guan untuk kemajuan ekonomi; dan

- Peningkatan kualitas ketertiban dan ketentraman masyarakat desa berdasarkan kebutuhan masyarakat desa.

\section{Tahap Pelaksanaan}

a. Pembangunan desa dilaksanakan sesuai dengan rencana kerja pemerintah desa.

b. Pembangunan desa dilaksanakan oleh pemerintah desa dengan melibatkan seluruh masyarakat desa dengan semangat gotong royong.

c. Pelaksanaan pembangunan desa dilakukan dengan memanfaatkan kearifan lokal dan sumber daya alam desa.

d. Pembangunan lokal berskala desa dilaksanakan sendiri oleh desa.

e. Pelaksanaan program sektoral yang masuk ke desa diinformasikan kepada pemerintah desa untuk diintegrasikan dengan pembangunan desa. 


\section{Tahap Pengawasan}

a. Masyarakat desa berhak mendapatkan informasi mengenai rencana dan pelaksanaan pembangunan desa.

b. Masyarakat desa berhak melakukan pemantauan terhadap pelaksanaan pembangunan desa.

c. Masyarakat desa melaporkan hasil pemantauan dan berbagai keluhan terhadap pelaksanaan pembangunan desa kepada pemerintah desa dan badan permusyawaratan desa.

d. Pemerintah desa wajib menginformasikan perencanaan dan pelaksanaan rencana pembangunan jangka menengah desa, rencana kerja pemerintah desa, dan anggaran pendapatan dan belanja desa kepada masyarakat desa melalui layanan informasi kepada umum dan melaporkan dalam musyawarah desa paling sediki 1 (satu) tahun sekali.

e. Masyarakat desa berpartisipasi dalam musyawarah desa untuk menanggapi laporan pelaksanaan pembangunan desa.

Peran Kepala Desa dalam proses pembuatan perencanaan pembangunan adalah kedudukan Kepala Desa dalam prosedur atau urutan pelaksanaan dalam menetapkan suatu perencanaan secara matang dalam hal pembangunan di suatu desa. Menyusun perencanaan Pembangunan Desa sesuai dengan kewenangannya dengan mengacu pada perencanaan pembangunan Kabupaten/Kota, pembangunan desa dilaksanakan oleh Pemerintah Desa dengan melibatkan seluruh masyarakat desa dengan semangat gotong royong.

Di era globalisasi ini fenomena pembangunan dihadapkan pada permasalahan yang semakin bertambah kompleks, maka untuk mewujudkan konsep masyarakat adil dan makmur berdasarkan Pancasila UndangUndangDasar 1945 bukanlah suatu hal yang mudah dalam pelaksanaannya. Agar pembangunan nasional dapat mewujudkan cita-cita seperti yang diinginkan oleh bangsa Indonesia, maka diperlukan adanya keterlibatan seluruh komponen bangsa secara proporsional. Pembangunan desa sebagai bagian dari pembangunan nasional merupakan ujung tombakdari pembangunan nasional yang strategis, maksudnya yaitu pembangunan desa merupakan bagian terpenting yang menentukan keberhasilan dari pembangunan nasional nantinya. Suksesnya pembangunan desa akan berimbas pada keberhasilan pembangunan nasional secara keseluruhan.

Dengan demikian maka untuk menumbuhkan partisipasi masyarakat diperlukan adanya pemimpin formal yang berfungsi mendorong dan memotivasi masyarakat untuk ikut berpartisipasi secara aktif dalam pembangunan desa. Kepala Desa sebagai pemimpin formal yang ada di desa, berfungsi sebagai administrator pemerintah, administrator pembangunan, dan administrator kemasyarakatan. Dengan demikian Kepala Desaharus mampu berperan sebagai motivator, komunikator serta mampu membina organisasi kemasyarakatan guna meningkatkan partisipasi masyarakat dalam proses pembangunan.

Wujud dari partisipasi masyarakat dalam hal ini yaitu diharapkan masyarakat ikut menjaga dan memelihara semua hasil pembangunan didesanya dengan sebaik-baiknya, bukan sebaliknya merusak. Semua masyarakat desa hendaknya dapat memanfaatkan hasil pembangunan dengan baik, namun tidak hanya sebatas memanfaatkannya, tetapi juga ikut menjaga kelestariannya agar dapat dimanfaatkan untuk generasi yang akan datang. Sesuai dengan hal tersebut, maka partisipasi masyarakat dalam memelihara hasil-hasil pembangunan yang ada di Desa telah dilaksanakan dengan baik oleh masyarakat secara keseluruhan, kegiatan pemeliharaan oleh masyarakat Desa bisa dilihat pada kondisi masjid maupun poskamling masih dalam kondisi yang baik dan sangat layak untuk digunakan.

Faktor komunikasi merupakan faktor yang sangat penting dalam menumbuhkan dan meningkatkan partisipasi masyarakat agar bersedia dengan sukarela ikut serta secara aktif dalam setiap kegiatan pembangunan di desanya. Kegiatan komunikasi yang dilakukan oleh Kepala Desa untuk meningkatkan partisipasi masyarakat dalam pembangunan didesanya, sudah sangat baik terbukti dengan partisipasi dari masyarakat yang sangat tinggi dalam pembangunan desa, hal ini dibuktikan dengan kehadiran masyarakat dalam setiap pelaksanaan program-program pembangunan. Kegiatan komunikasi yang dilakukan oleh Kepala Desa selain dilakukan dalam sebuah rapat pertemuan dan musyawarah juga dilakukan pada saat Kepala Desa melakukan kunjungan ke wilayah lingkungan RT/RW.

Alokasi Dana Desa (ADD) dimaksudkan untuk membiayai program pemerintahan desa dalam melaksanakan kegiatan pemerintahan dan pemberdayaan masyarakat dan dengan adanya bantuan dan dari Pemerintah Kabupaten berupa ADD tersebut telah mendukung dan membantu pelaksanaan program pembangunan yang ada di Desa. Namun, di sisi lain, dengan adanya bantuan tersebut telah membuat sebagian masyarakat menjadi mempertimbangkan bantuan atau sumbangan apa yang akan diberikan untuk pembangunan didesanaya karena masyarakat lebih cenderung untuk menunggu bantuan dana dari Pemerintah. Kecenderungan berpikir seperti ini munculkarena dengan adanya ADD tersebut telah membuat masyarakat jadi menggantungkan dalam hal pembiayaan pembangunan yang akan dilaksanakan di Desa. Masyarakat masih ada yang berangapan bahwa pembangunan didesa mereka sepenuhnya dibiayai oleh Pemerintah, 
padahal maksud dari ADD itu sendiri ialah untuk mebiayai program pemerintahan desa dalam melaksanakan kegiatan pemerintah dan pemberdayaan masyarakat, jadi tidak sepenuhnya hanya untuk pembangunan fisik desa saja.

Faktor penghambat bagi Kepala Desa di dalam menyampaikan informasi dan program-program pembangunan kepada masyarakat desa yang seringkali dihadapi yaitu faktor rendahnya tingkat pendidikan yang dimiliki oleh sebagian besar masyarakat. Dengan tingkat pendidikan yang rendah seperti ini, menjadikan hambatan kepada Kepala Desa di dalam penyampaian setiap informasi dan program-program pembangunan, mereka kurang tanggap, tidak cepat mengerti dan memahami apa yang disampaikan oleh Kepala Desa. Oleh karena itu diharapakan agar warga masyarakat saling melengkapi, maksudnya disini ialah untuk masyarakat yang berpendidikan tinggi diharapakan agar dapat membantu upaya Kepala Desa di dalam menyampaikan informasi tentang program-program pembangunan kepada masyarakat yang berpendidikan rendah, karena mereka lebih cepat mengerti dan memahami tentang program-program pembangunan yang akan dilaksanakan. Sedangkan untuk masyarakat yang berpendidikan tinggi yang enggan melakukan pekerjaan kasar, diperlukan pendekatan oleh Kepala Desa kepada mereka dengan memberikan pengertian dan arahan bagaimana pentingnya partisipasi tenaga mereka dalam kegiatan pembangunan seperti yang dilakukan oleh masyarakat yang mempunyai tingkat pendidikan rendah dalam membangun desa.

\section{KESIMPULAN}

Kepala Desa adalah pimpinan pemerintah desa yang secara langsung dicalonkan oleh masyarakat setempat ditetapkan dengan surat keputusan pejabat yang berwenang mengangkat dan memberhentikan, yaitu Bupati/Walikota atas nama Gubernur. Kepala Desa mempunyai tugas yang cukup berat dalam penyelenggaraan pemerintah desa. Koordinasi mutlak diperlukan dalam sebuah organisasi, karena organisasi merupakan pelaksana fungsi manajemen dari seorang pemimpin dalam rangka menghimpun orang-orang, materi dan metode untuk bekerjasama kearah pencapaian tujuan. Pengawasan adalah proses pengamatan pelaksanaan seluruh kegiatan organisasi untuk menjamin agar pekerjaan yang sedang dilakukan berjalan sesuai dengan rencana yang telah ditentukan sebelumnya. Pengawasan dilakukan untuk mengetahui tingkat keberhasilan suatu organisasi di dalam melaksanakan program-program yang telah direncanakan, apakah didalam pelaksanaannya telah sesuai dengan apa yang direncanakan ataukah belum.

Kepala Desa sebagai pemimpin formal di desa yang merupakan administrator pemerintah, administrator masyarakat dan administrator pembangunan mempunyai peranan yang sangat penting dalam menumbuhkan, menggerakkan dan meningkatkan partisipasi masyarakat untuk ikutaktif dalam kegiatan pembangunan desa. Alokasi Dana Desa (ADD) merupakan dana bantuan Pemerintah Kabupaten yang dimaksudkan untuk membiayai program pemerintah desa dalam melaksanakan kegiatan pemerintahan dan pemberdayaan masyarakat, karena dengan bantuan ini dapat membantu terlaksananya pembangunan desa dalam hal pembiayaan atau pembangunan. Oleh karena itu, kegiatan pendampingan masyarakat selain penyuluhan yang diberikan oleh tim pengabdian, pendampingan lebih lanjut dalam membangun kerjasama antara Kepala Desa dan BPD serta masyarakat menjadi penting dilakukan.

\section{DAFTAR PUSTAKA}

Ibnouf, M. H., Sheqwarah, M. N., \& Sultan, K. I. 2015. An Evaluation of the Participatory Learning and Action (PLA) Training Workshop. Journal of Agricultural Science, 7(12), 144-150. https://doi.org/10.5539/jas.v7n12p144

Ketaren S. 2008. Pengantar Teknologi Minyak dan Lemak Pangan. UI-Press. Jakarta.

Peraturan Perundang-Undangan.

Rozalli, A. 2011. Pelaksanaan Otonomi Luas Dengan Pemilihan Kepala daerah Secara Langsung. Rajawali Pers. Jakarta.

Undang-Undang Nomor 23 Tahun 2014 tentang Pemerintah Daerah, Lembaran Negara Republik Indonesia Tahun 2014.

Undang-Undang Nomor 6 Tahun 2014 tentang Desa, Lembaran Negara Republik Indonesia Tahun 2014. 